\title{
GROWTH AND YIELD OF OKRA AS INFLUENCED BY HILL ELEVATION AND PLANT DE-DETOPING IN HILL SLOPE CONDITION
}

\author{
Z. A. FIROZ ${ }^{1}$, K. M. NASIRUDDIN ${ }^{2}$, M. F. MONDAL ${ }^{3}$ \\ AND A. M. FAROOQ ${ }^{4}$
}

Keywords: Okra yield, plant growth, hill elevation, and de-topping.

Okra (Abelmoschus esculentus L. Moench) is an annual vegetable crop in tropical and sub-tropical parts of the world (Thakur and Arora, 1986). It is one of the important nutritious vegetable crops grown round the year in Bangladesh. Its every $100 \mathrm{~g}$ green pod contains protein $1.8 \mathrm{~g}$, carbohydrate $6.4 \mathrm{~g}$, fibre $1.2 \mathrm{~g}$, Vitamin C $18 \mathrm{mg}$, and Ca $90 \mathrm{mg}$ (Rashid, 1999). Vegetable availability in Bangladesh is primarily concentrated in the rabi season. Of the total vegetable production, around $70 \%$ is produced during rabi season and the rest $30 \%$ in kharf season (Hossain, 1992). There is crucial need to increase vegetable production during rainy season through proper management techniques or introducing new rainy season vegetables. Okra as a summer/rainy season vegetable can play a vital role in this regard. Chittagong Hill Tracts region is about $10 \%$ the total area of Bangladesh. This area has great potentiality for growing okra during rainy season by using high yielding varieties with improved production practices. The yield of different crops in hill is below the national average and even in some cases very poor. Low fertilizer consumption coupled with lack of high yielding varieties and improved management practices resulted in low productivity in hilly area. Performance of okra has not been assessed when grown at different hill elevations. But yields of different crops were influenced by hill elevation (Molla et al., 1998; and Uddin and Firoz, 2001). Yield of any crop is influenced by proper management of cultural practices. Detopping is a part of management practices which initiates new shoot and branches and can help increase yield of okra (Baten, 1999). But farmers are not aware of the beneficial effects of it. The experiment was, therefore, carried out to find out the effect of hill elevation and plant de-topping on the growth and yield of okra in hill slope condition during rainy reason.

The experiment was conducted at the Hill Agricultural Research Station, Khagrachari from June to November 2004. The treatments of the experiment were 4 hill elevations viz., 0-5 m, 5-10 m, 10-15 m and 15-20 m and 4 plant detopping viz, control, 3, 6 and 9-leaf stage. The experiment was laid out in split-

\footnotetext{
${ }^{1}$ Senior Scientific Officer (Hort.), Agricultural Research Station, BARI, Raikhali, Chandraghona, Rangamati, ${ }^{2}$ Professor, Bangladesh Agricultural University (BAU), Mymensingh, ${ }^{3}$ Professor, BAU, Mymensingh, ${ }^{4}$ Vice-Cancellor, Sher-e-Bangla Agricultural University (SAU), Dhaka, Bangladesh.
} 
plot design with three replications keeping hill elevation in main plot and 4 levels of de-topping in sub-plots. The unit plot size was $3.0 \times 2.4 \mathrm{~m}$. The plot and blocks were separated by $0.5 \mathrm{~m}$ and $1.0 \mathrm{~m}$, respectively. Seeds of okra were sown on 03 July 2004 at spacing of $60 \mathrm{~cm} \times 40 \mathrm{~cm}$. Fertilizers were used at the rate of 150, 100, and $150 \mathrm{~kg} / \mathrm{ha}$ Urea, TSP and MP, respectively. Cowdung was used 10 t/ha during land preparation. Intercultural operations were done as and when necessary. Harvesting of fruits started on 20 August and continued upto 30 October 2004. Data of plant characters were recorded from ten selected plants, but yield was recorded on plot basis. Collected data were subjected to statistical analysis. Treatment means were judged by Duncan's Multiple Range Test (DMRT).

Table 1. Main effect of hill elevation and plant de-topping on growth of okra plant.

\begin{tabular}{|c|c|c|c|c|c|c|}
\hline Treatments & \begin{tabular}{|} 
Plant \\
height \\
(m)
\end{tabular} & $\begin{array}{l}\text { Plant } \\
\text { survival } \\
(\%)\end{array}$ & $\begin{array}{l}\text { Branching } \\
\text { plant (\%) }\end{array}$ & $\begin{array}{c}\text { No. of } \\
\text { branches/ } \\
\text { plant }\end{array}$ & \begin{tabular}{|c} 
Internode \\
length \\
(cm)
\end{tabular} & $\begin{array}{l}\text { Fruit yield } \\
\text { (T/ha) }\end{array}$ \\
\hline \multicolumn{7}{|l|}{ Hill elevation } \\
\hline $0-5 \mathrm{~m}\left(\mathrm{H}_{1}\right)$ & $1.22 \mathrm{a}$ & $88.1 \mathrm{a}$ & $49.4 a$ & $1.4 \mathrm{ab}$ & 9.la & $14.32 \mathrm{a}$ \\
\hline $5-10 \mathrm{~m}\left(\mathrm{H}_{2}\right)$ & $1.16 \mathrm{~b}$ & 87.3a & $49.7 \mathrm{a}$ & 1.6a & 8.7ab & 13.63a \\
\hline $10-15 \mathrm{~m}\left(\mathrm{H}_{3}\right)$ & $1.13 b$ & 77.lb & $21.9 b$ & $1.3 \mathrm{~b}$ & $8.3 \mathrm{~b}$ & $12.38 \mathrm{a}$ \\
\hline $15-20 \mathrm{~m}\left(\mathrm{H}_{4}\right)$ & $1.15 b$ & $76.3 b$ & $21.3 b$ & $1.2 \mathrm{~b}$ & $8.3 \mathrm{~b}$ & $11.41 b$ \\
\hline \multicolumn{7}{|l|}{ De-topping level } \\
\hline No de-topping $\left(\mathrm{D}_{0}\right)$ & $1.42 \mathrm{a}$ & $84.5 a$ & $19.4 \mathrm{c}$ & $1.2 \mathrm{~b}$ & $9.2 \mathrm{a}$ & $13.55 b$ \\
\hline $\begin{array}{l}\text { De-topping at 3-leaf } \\
\text { stage }\left(D_{1}\right)\end{array}$ & $1.24 \mathrm{~b}$ & $82.3 b$ & $41.5 \mathrm{a}$ & 1.6a & 8.9ab & $15.84 \mathrm{a}$ \\
\hline $\begin{array}{l}\text { De-topping at } 6 \text { leaf } \\
\text { stage }\left(D_{2}\right)\end{array}$ & $1.9 \mathrm{c}$ & $81.4 \mathrm{bc}$ & $44.4 \mathrm{a}$ & $1.4 \mathrm{ab}$ & $8.5 b c$ & $12.66 \mathrm{~b}$ \\
\hline $\begin{array}{l}\text { De-topping at 9-leaf } \\
\text { stage }\left(D_{3}\right)\end{array}$ & $0.92 \mathrm{~d}$ & $80.4 \mathrm{c}$ & $37.0 \mathrm{~b}$ & $1.3 \mathrm{~b}$ & 7.8c & $9.68 \mathrm{c}$ \\
\hline
\end{tabular}

Means followed by different letter (s) are significantly different at 5\% level by DMRT

Effect of hill elevation is presented in Table 1. The highest plant height (1.22 $\mathrm{m})$ was obtained in the plants grown on $0-5 \mathrm{~m}$ hill elevation. The lowest value $(1.13 \mathrm{~m})$ for plant height was recorded on $10-15 \mathrm{~m}$ hill elevation followed other hill elevations. The maximum plant survival (88.1\%) was achieved on 0-5 m hill elevation followed by 5-10 m hill elevation (87.3\%). Higher hill elevation showed the lowest plant survival. Identically superior branching plants were produced on $0-5$ and $5-10 \mathrm{~m}$ hill elevation (49.4\% and $49.7 \%$, respectively) to that of $10-15 \mathrm{~m}$ and $15-20 \mathrm{~m}$ hill elevation (21.9\% and $21.3 \%)$. Variation in 
number of branches per plant due to hill elevation was found significant. Number of branches per plant was maximum (1.6) on 5-10 m hill elevation, which was similar to 0-5 m hill elevation (1.4). Internode length of okra plant decreased with the increase of hill elevation. The highest internode length $(9.2 \mathrm{~cm})$ was obtained from 0-5 m hill elevation (lower elevation), which was at par to the treatment of 5-10 m hill elevation $(8.7 \mathrm{~cm})$. As plant height was higher in 5-10 m hill elevation, the internode length was also higher in this treatment. The yield of okra per hectare varied significantly due to hill elevation. The plants grown at lower hill elevation (0-5 m high of hill) produced the highest yield (14.32 t/ha), which was identical to 5-10 m hill elevation (13.63 t/ha) whereas, the lowest yield (11.41 t/ha) was obtained at $15-20 \mathrm{~m}$ hill elevation. This was due to better plant growth, number and weight of fruits/plant and longer crop duration of plants gown at 0-5 m hill elevation.

Plant height in non de-topping treatment was significantly higher than those of all other de-topping treatments (Table 1). Due to removal of top part of shoot plant growth increased horizontally rather than vertically. The survival percentage was minimum (84.5) in no de-topping which decreased gradually with increasing leaf stage at $82.3,81.4$, and $80.4 \%$ in 3,6 , and 9-leaf stage detopping. De-topping at more leaf stage had negative effect in plant survivability. 6-leaf stage de-topping produced the most satisfactory branching plants (44.4\%) followed by 3-leaf stage de-topping (41.5\%), while the lowest number of branching plant (19.4\%) was found in no de-topping plant. The result indicates that de-toping has vital role in producing branchy plants. Detopping also showed significant variation in the number of branches per plant. The maximum number of branches per plant (1.6) was found at 3-leaf stage detopping, which was statistically identical with 6-leaf stage de-topping (1.4) and the lowest number of branches per plant (1.2) was found in control treatment (without de-topping). In control treatment, number of branches per plant was the lowest as the apex of the shoot was not broken, which maintained apical dorminance thus prohibiting the lateral branching. But in case of de-topping, the apical dorminance was removed which naturally promoted auxillary buds into side branches. This is an agreement with the finding of Baten (1999). Internode length was decreased with the increasing of leaf stage of de-topping. The plants of the control treatment (no de-topping) produced the longest internode $(9.2 \mathrm{~cm})$, which was at par with 3-leaf stage de-topping $(8.9 \mathrm{~cm})$. The shortest internode $(7.8 \mathrm{~cm})$ was recorded in 9-leaf stage de-topping. Yield of okra was also significantly influenced by de-topping. The plants pruned at 3leaf stage resulted in the highest yield (15.84 t/ha) and 9-leaf stage of detopping gave the lowest yield (6.68 t/ha). Arora and Malik (1984) also got higher yield in ribbed gourd by pruning. 
Table 2. Interaction effect of hill elevation and plant de-toping on growth of okra plant.

\begin{tabular}{|c|c|c|c|c|c|c|c|}
\hline \\
\hline & ments & $\begin{array}{l}\text { Plant } \\
\text { height } \\
(\mathrm{m})\end{array}$ & $\begin{array}{c}\text { Plant } \\
\text { survival } \\
(\%)\end{array}$ & $\begin{array}{l}\text { Branching } \\
\text { plant (\%) }\end{array}$ & \begin{tabular}{|c|} 
No. of \\
branches/ \\
plant
\end{tabular} & $\begin{array}{l}\text { Internode } \\
\text { length } \\
(\mathrm{cm})\end{array}$ & $\begin{array}{l}\text { Fruit yield } \\
\qquad(\mathrm{t} / \mathrm{ha})\end{array}$ \\
\hline \multirow{4}{*}{$\mathrm{H}_{1}$} & $\mathrm{D}_{0}$ & $1.49 a$ & 90.8 & $22.5 \mathrm{~cd}$ & 1.3 & 9.6 & 13.87 abcde \\
\hline & $\mathrm{D}_{1}$ & $1.29 \mathrm{~cd}$ & 87.5 & $60.8 \mathrm{a}$ & 1.6 & 9.3 & $17.07 \mathrm{a}$ \\
\hline & $\mathrm{D}_{2}$ & $1.17 \mathrm{ef}$ & 88.2 & $62.5 \mathrm{a}$ & 1.5 & 9.1 & $15.40 \mathrm{ab}$ \\
\hline & $\mathrm{D}_{3}$ & 0.941 & 85.8 & $51.7 \mathrm{ab}$ & 1.3 & 8.2 & 10.93 bcde \\
\hline \multirow{4}{*}{$\mathrm{H}_{2}$} & $\mathrm{D}_{0}$ & 1.43ab & 89.2 & $36.7 b c$ & 1.2 & 9.6 & $14.70 \mathrm{abc}$ \\
\hline & $\mathrm{D}_{1}$ & $1.24 \mathrm{de}$ & 89.2 & 49.2ab & 2.0 & 8.8 & $17.03 \mathrm{a}$ \\
\hline & $\mathrm{D}_{2}$ & $1.05 \mathrm{gh}$ & 85.8 & $57.5 \mathrm{a}$ & 1.6 & 8.6 & 13.20 abcde \\
\hline & $\mathrm{D}_{3}$ & 0.931 & 85.0 & 55.3a & 1.4 & 7.9 & $9.56 \mathrm{de}$ \\
\hline \multirow{4}{*}{$\mathrm{H}_{3}$} & $\mathrm{D}_{0}$ & $1.36 \mathrm{bc}$ & 80.0 & $9.2 \mathrm{~d}$ & 1.2 & 8.7 & 13.67 abcde \\
\hline & $\mathrm{D}_{1}$ & $1.21 \mathrm{e}$ & 76.7 & 28.3c & 1.3 & 8.7 & $14.37 \mathrm{abcd}$ \\
\hline & $\mathrm{D}_{2}$ & $1.02 \mathrm{~h}$ & 75.8 & 29.lc & 1.4 & 8.2 & 12.23 bcde \\
\hline & $\mathrm{D}_{3}$ & $0.91 \mathrm{i}$ & 78.3 & $20.8 \mathrm{~cd}$ & 1.2 & 7.7 & $9.23 \mathrm{e}$ \\
\hline \multirow{4}{*}{$\mathrm{H}_{4}$} & $\mathrm{D}_{0}$ & $1.39 b$ & 75.8 & $9.2 \mathrm{~d}$ & 1.1 & 8.7 & 11.97 bcde \\
\hline & $\mathrm{D}_{1}$ & $1.20 \mathrm{c}$ & 75.8 & $27.5 \mathrm{c}$ & 1.3 & 8.7 & $14.90 \mathrm{ab}$ \\
\hline & $\mathrm{D}_{2}$ & $1.11 \mathrm{fg}$ & 75.8 & $28.3 c$ & 1.2 & 8.1 & 9.80 cde \\
\hline & $\mathrm{D}_{3}$ & 0.901 & 75.0 & $20.0 \mathrm{~cd}$ & 1.2 & 7.6 & $8.28 \mathrm{e}$ \\
\hline \multicolumn{2}{|c|}{ CV (\%) } & 3.65 & 2.12 & 5.9 & 6.5 & 11.5 & 9.66 \\
\hline
\end{tabular}

Means followed by different letter (s) are significantly different at $5 \%$ level by DMRT

Hill elevation $\quad: \mathrm{H}_{1}=0-5 \mathrm{~m}, \mathrm{H}_{2}=5-10 \mathrm{~m}, \mathrm{H}_{3}=10-15 \mathrm{~m}, \mathrm{H}_{4}=15-20 \mathrm{~m}$

De-toping level $\quad: \mathrm{D}_{0}=$ No de-topping, $\mathrm{D}_{1}=$ 3-leaf stage de-topping,

$\mathrm{D}_{2}=$ 6-leaf stage de-topping, $\mathrm{D}_{3}=9$-leaf stage de-topping

Performance of different treatment combinations is presented in Table 2. Identically the tallest plants were produced by $\mathrm{H}_{2} \mathrm{D}_{\mathrm{O}}(1.49 \mathrm{~m})$ and $\mathrm{H}_{1} \mathrm{D}_{0}(1.43 \mathrm{~m})$. Interaction effect of hill elevation and de-topping on plant survival percentage was not significant (Table 2). However, it ranged from 75 to $90.8 \%$ and higher percentage was in lower hill elevation with less leaf stage de-topping and survival percentage gradually decreased with the increase of hill elevation and de-toping with more leaf stage. The highest branching plant (62.5\%) was obtained in $\mathrm{H}_{1} \mathrm{D}_{2}$ and the lowest branching plants were produced in $\mathrm{H}_{3} \mathrm{D}_{0}(9.1 \%)$. The effect of hill elevation and de-topping on internode length of okra plant was not significant. However, numerically it was maximum in $\mathrm{H}_{1} \mathrm{D}_{0}(9.6 \mathrm{~cm})$ and minimum $(7.6 \mathrm{~cm})$ in $\mathrm{H}_{4} \mathrm{D}_{3}$. Plants grown at $0-5 \mathrm{~m}$ hill elevation with 3-leaf stage de-topping produced the highest yield (17.07 t/ha) and the lowest yield (8.28 t/ha) was obtained from 15-20 m hill elevation with 9-leaf stage de-topping.

The above result revealed that $0-5 \mathrm{~m}$ hill elevation with 3-leaf stage detopping is most suitable for better production of okra in hill slope condition during the rainy season. 